Editorial

\title{
Redefining the Social Contract
}

Higher Education Policy (2006) 19, 269-286. doi:10.1057/palgrave.hep.8300130

The English gentleman always plays fairly, until he looses. And then he changes the rules of the game.

George Bernard Shaw

(Man and Superman)

\section{Introduction}

Establishing a synthesis is one of the lasting challenges facing the student of higher education - and very particularly, in the area of higher education policy pursued comparatively. The difficulties he, or she, must confront are considerable for the simple reason that there is no one master perspective, which so far has managed to bring the 20 or so fields, which contribute to the study of this domain (Becher, 1998) together in elegant, analytical harmony. This is not a new challenge. On the contrary, it has been with us almost as long as higher education has itself been studied comparatively. Many systems may be studied within in a narrow and tightly focused range of disciplines often a single one. Conversely, only a very limited number of systems may be treated by perspectives drawn simultaneously from many disciplines. To have many systems analysed within the framework of five or more disciplinary canons must surely be the Holy Grail of our métier. If one adheres to the quantitative approach, one multiplies the countries, and restricts the disciplines involved. Conversely, if one subscribes to a qualitative mode of inquiry, one expands the disciplinary base, but finds oneself forced to cut back the number of countries, or systems, covered. This is higher education's very own edition of what is known to the classical French theatre as a Cornelian dilemma.

\section{Quantification, Ranking and League Tables}

Agreed, there are always the delights of quantification and the simplistic recourse to League Tables - national, regional or, rarer by far but not wholly unknown, worldwide rankings. Rankings bring much joy to those that have - 
to use a Victorian phrase - 'risen beyond their station' — just as they also cause great heart-searching to those who see their establishments apparently sinking into the slough of disgrace and despond. But such exercises, stimulating though they might be to institutional leadership, governments and journalists, are in effect a species of trade-off between ostensible clarity and essential plausibility. As descriptors - which is what they are - they have little or no power of explanation that is readily perceivable to those who scan them. Rather, they serve a function not greatly distant from that test of the imagination psychiatrists inflict upon their victims from time to time. Rankings are higher education's version of the Rohrsach Test. They allow explanations privately to be projected by institutional leaders and national administrations who, wise after the event, may thus justify both their rejoicing and their strategy - institutional or national. Or, if fate and the performance indicators have not been kind to them, this same device may serve to generate collective commiseration, lamentation and recrimination in face of apparently obvious failure! And doubtless, the determination to do better next time.

Still, the point could be argued that the extraordinary rise of the quantitative approach to higher education policy in recent times reflects the geographic extension of higher education itself - the process sometimes marshalled under the rubric of 'globalization'. By the same token, quantification also reflects the inability of studies in higher education in their current state easily to follow in a persuasive and timely fashion the sheer physical expansion, complexity and ever-moving target that higher education has become in the course of the past quarter century.

\section{The Quest for Synthesis}

This is not to say that brilliant examples of synthesis are lacking. Far from it. In recent times, the monumental work of Manuel Castels into the Information Society, its political and sociological ramifications stands in the forefront. And in an earlier setting, the approach pioneered by Immanual Wallerstein's World Systems Analysis shows this path to be far from untrodden. Nevertheless, the problem remains largely intact - if it is not made even more intractable with the injection of the conviction that change is now to be seen as much by the institutions of higher education as by those who observe them closely as a continual and unceasing dynamic.

\section{The Sudden Discovery of an Earlier Arcadia}

Scholarship is about imposing order, clarity and explanation onto a world otherwise chaotic or, to the less pessimistic, a world more complex, though this latter often entails an anachronistic way of looking at things, if only because 
the world of complexity today imposes its artefacts upon the world of yesterday (Nybom, 2003). Faced with 'fast capitalism' with today's sustained and pressing demand for higher education, with public resources subject to conditionality and accountability, and with the fragmentation of institutional identity and mission, we tend to look back enviously to the days when an apparent consensus still held around what the university stood for and when, by common consent, public monies supported it, fully and generously. Thus, we reinterpret the age previous to the present, as a Golden Era, a suddenly discovered Arcadia, when everything appeared straightforward by contrast to the myriad challenges higher education faces today. It is, of course, an interpretation deeply erroneous though all too often repeated.

The Golden Age of our immediate predecessors was no less nerve wracking and complex for those who had the responsibility of shaping it. And, if they dwelt in Arcadia, few of them realized their luck. If the truth were out, the past age appears golden only because those who shaped it largely succeeded in their prime task, for instance, in moving higher education into a new setting - mass higher education. The Golden Age is golden because we know the outcome. The outcome of our present designs, however, still hangs in the balance. We are then only too well aware of the complexity confronting us, though perhaps our students will, in later days, see us too as dwellers in Arcadia.

\section{The Joys of Doxology, the Predictability of Visions}

Even so, the need for order, explanation and the sense of having mastery over our own Fate are existential needs that become especially pressing when frontiers, administrative delineations, institutional typologies and the basic framework within which higher education has operated for so long no longer provide us with so firm a grasp and so sure a purchase over it as we once thought we had. To this situation, there are two possible responses: to huddle around one central paradigm or, on the contrary, to strike out in quest of a broader, more encompassing explanative set.

The first course has powerful advocates behind it. It may be called the Festung der Wirtschaflichern, the Fortress of Economicism. Under the backing of such intergovernmental agencies as the Organization for Economic Cooperation and Development and the World Bank, it subsumes higher education into the great dissolvent of the economic perspective.

The second however, seeks insight from what may be seen as quasimetaphysical constructs - the Knowledge Society, the Knowledge Economy, the Learning Society. These differ from the first in being grounded on a predicted vision towards which, whether we like it or not - everything supposedly drives. Armed with this latter eschatology, the work of scholarship is to identify those trends; forms of institutional or human behaviour, which 
show how far we have gone down this road, and, though more implicitly than explicitly, how far we have already committed ourselves, perhaps unwittingly, to the inevitable outcome thus predicted.

The former seeks refuge and intellectual coherence around a single discipline as a species of latter-day doxology, that is, an authoritative text. The latter seeks evidence through different disciplinary combinations to give pragmatic support to the clarity of the vision ineffable. What is very clear in both approaches is the implicit consensus that we stand at an historical watershed, at a break point so radical that it renders our present adventure without precedent. There are, of course, many ways of presenting this new awareness. The more polemical among the analytical fraternity cast it in such apocalyptic terms as 'The End of History and the New Man' (Fukuyama, 1992). Others confine their vision to a particular dimension in the affairs of government; thus, for instance, the notion of New Public Management (Pollitt, 1993; see also Liesyte and Kiziene, in this issue) The concept of a New Social Contract is a third. This is an interesting perspective since it appears to combine both the historical dimension and an eschatology firmly rooted in the vision of a university - or higher education system - that stands on the horizon.

\section{A New Social Contract: Questions impertinent but necessary}

Yet, the construct of a 'social contract' applied to higher education is not without its ambiguities. Is it to be understood as part of a wider, more pervasive redefining of the relationship between the individual, the collectivity, government, business and power? Are we to understand it as limited solely within the confines of higher education? There is a third possibility, and one has to admit, its narrowest application, that turns around the social dimension within higher education. Defined in this manner, the notion of a social contract involves such dimensions as who goes to higher education? Who does not? Who succeeds? This, in effect, is an individualist perspective. In contrast, other questions broach a different perspective. What is learned? What are the consequences for society of that learning in terms of social behaviour, social cohesion, solidarity, collective responsibility? They all involve the way higher education shapes collective identity. It is, in short, a social contract as distinct, for example, from an economic contract and, as such subordinates this latter to the primary perspective.

There are, however, variations of purpose or final intention involved here as well. And very particularly the central purpose of such a social contract. Is the idea of a social contract to apply to higher education alone? Does it have a latent agenda as well as a manifest one? Does the latent agenda involve ensuring the 'conditions of sustainability' for a particular economic order by 
rooting the values it requires explicitly and more firmly amidst those higher education is called upon to pass on? Put crudely, are we to accept the idea that a new social contract is simply an exercise in ensuring the social acceptability of a very particular economic doctrine, a species of cache sexe to the more outrageous forms of Ultra-liberalism, which was once known as supply side economics?

\section{Ambiguities}

These are not the only ambiguities that lurk beneath the surface when higher education policy is viewed in terms of redefining the social contract for there is also a very specific and operational meaning that has made its way into the vocabulary of some students of higher education. It emerges in the term 'contractualization' and, while not universally employed, it is nevertheless in current usage in certain systems of higher education - principally France, Spain and Italy, though the process it involves is well to the fore elsewhere. For these systems, contractualization might, with considerable mental gymnastics, lend itself to being interpreted as a first step towards a more far-reaching venture in redefining a social contract between government and higher education.

In its present form, however, contractualization applies to one specific domain namely the allocation of resources. In return for the fulfilment of selfdetermined targets, the institution agrees to commit itself to over a given period. On the basis of such agreed terms, public authority supports the establishment from the national, or regional, coffers. The operational relationship between university and public authorities resides no longer in the arrangement often alluded to as 'historic incrementalism', that is, last year's budget plus an inbuilt or negotiated percentage to cover inflation or to take account of new priorities placed on higher education. Such a shift in the financing of universities is not, of course, an exclusivity of Southern Europe. Elsewhere it navigates under different flags: 'conditional financing' in the Netherlands, performance related financing in the UK or, as a variation on the same theme, performance-linked budgeting, which imparts a certain elasticity to the ties between performance and budget in contrast to the death grip the former has over the latter in John Bull's Island.

\section{The Delicate Relationship between Contractualization and the New Social Contract}

Contractualization, conditionality and output-based budgeting, though they represent a fundamental change in the relationship between higher education 
and government and by extension from the latter, society as well are, however, best set aside when dealing the notion of a 'social contract' in its broader meaning. They are best set aside for three excellent reasons. First, because though they are indeed legal contracts, it does not follow that they can be seen as forerunners to revising 'the social contract' defined sensu lato. Second, if we were to conflate resource allocation with all that goes on in higher education, we open the way to giving both a limitless legitimacy and plausibility to the quantifying at best or the dismissal at worst, of the basic social values that tie higher education to society. To say the least, this would be a reductio ad absurdum, quite apart from equating such subtle matters as the development, training and nurturing of human talent and sensitivities with the act of bean counting. Thirdly, contractualization, in the sense currently used, stands as an instrument, a technical device, that serves very specific and immediate ends - to raise institutional performance under threat of chastisement or to drum up a more enterprising boldness by institutional leadership to the development of institutional strategy through the setting out of tempting incentives (Neave, 1996).

The forging of a technical instrumentality, explicitly based on a relationship that is formally contractual, does not, on its own, herald the wholesale overhaul of the Social Contract. It can just as well be seen as fulfilling an operational and technical function without the slightest penetration into, still less have implications for, the world of political theory or political philosophy. Confined to the limited sphere of the instruments of government, governing and governance, contractualization may indeed be a first step. But if it is necessary to shift the frame of debate onto perspectives new, it is not sufficient on its own to allow us to conclude that the Social Contract between rulers and ruled is about to be stood on its head. Rather, scepticism and scholarly detachment both suggest that contractualization in this form is best viewed part of a different order of things, namely of governments tightening up and refining the procedures, ways and means of judging institutional performance.

\section{The Consequences of Redefinition}

Nevertheless, some do care to see this particular straw as the first to fly aloft under the gusts of more robust winds of change. Re-defining today's higher education policy in terms of revising the social contract involves redefinition at two levels. The first sets the concept of a Social Contract within that pervasive tendency already mentioned, namely its assimilation as part of the drive towards a doxology overwhelmingly economic. At a second level, this same process of re-definition entails a very substantive reshaping to the usual understanding of what is involved in the concept of the Social Contract. 


\section{A Brief Historical Excursion}

Both approaches are intimately linked for change in the former entails change in the latter. For this reason, it raises some very basic questions. Can the New Social Contract thus defined be said to stand in lineage to the contractualist political philosophers of the 17th and 18th century Enlightenment - Hobbes, Locke and Rousseau, not to mention that derivative contractualist, Adam Smith? Is the new social contract at one and the same time a bid to change the order within the Pantheon of contractualist philosophers the better to bring Smith to the fore and in so doing bestow a further legitimacy upon his present day adepts - a legitimacy all the more weighty for being grounded in the general contractualist school of thought and doubly so with Smith's elevation to the status of primus inter pares rather than a Johnny-come-lately? In short, are we to see the notion of a New Social Contract not simply as placing society upon a new footing but also as a historiographical shift in one of the major theories that has exercised a prime influence in shaping democracy itself, that is the contract between rulers and ruled?

\section{Three Theorists of the Social Contract}

With one major exception, the classic contractualist philosophers sought to explain the social and political order in terms of a contract reached in a distant - and often mythical - past between the individual and the collectivity. Such a mythical covenant served as a device for dealing with then contemporary issues and to legitimize society's current structure.

For Hobbes, the central issue was how to control violence and the internecine strife that attended man in his natural state, a major concern for one who had lived through the English Civil War of the 1640s and whose time also coincided with mass and bloody religious warfare that had embraced wide swathes of Europe for the best part of 30 years (1618-1648). Since, for Hobbes, the lot of Man in his natural state was far from enviable, individuals got together to give up their rights to mutual massacre and mayhem. The Social Contract had them placing these indulgences exclusively in the hands of a single all-powerful authority, which Hobbes termed Leviathan, often seen, as symbolic of the strong State. In this setting, the social contract rested on the individual's renouncing those capacities he possessed in the State of Nature. In return for the exclusivity thus granted, Leviathan upheld the social peace by imposing an equal and rigorous subordination of all to his rule.

For Locke, however, the basic issue of the social contract involved a different perspective, which dwelt less on the avoidance of civil strife but rather on identifying the conditions that sustained the social order. For him, the 
central concern turned around the socialization of individuals and the relationship between them; hence, his two preoccupations with early childhood education, on the one hand, and with religious toleration, on the other. With these two concerns went the quest for a central and shareable institution to ensure social stability without that institution's degenerating into either tyranny or arbitrariness. The Lockean contract in effect made the access to and the possession of goods and very especially property the central pillar in social stability, but left its attainment to the abilities of the individual. The opportunity to enjoy the fruits of property owning was thus the essence of the contract between rulers and ruled. So long as the former did not threaten 'the spirit of possessive individualism' among the latter, the political order of church, parliament and monarchy was preserved.

While Adam Smith obviously has his place in the Pantheon of the fathers of contractualism, his version of the Social Contract differed markedly in both purpose and interpretation from either Hobbes or Locke. In the first place, he made no a priori assumption about man in the state of nature. Rather, his primary concern lay with what bound society together on a daily basis rather than having recourse to a mythical past to explain contemporary developments and still less to adumbrate on Man's propensities for good or evil when in a presumable state of savagery. This was a major departure from the previous thrust of contractualism. By leaving aside the question of Man's earlier condition, Smith, dealt a heavy blow to the notion that then underpinned a centuries-long justification for established authority in an age of religious belief, namely the Fall from Grace. This was not, however, a direct challenge in itself. Rather, it may be seen as an indirect challenge by omission. But none could deny it was aimed at the ecclesiastical authorities and against the religious dimension in the Social Contract that Hobbes brought wholly under the oversight of Leviathan, and which Locke, differing from Hobbes, saw as an essential condition for sustaining the social order through the notion of religious toleration.

Smith steered contractualist theory onto a new path. First, he sought the basis for his theory of contract not in a deductive concept of agreement arrived at sometime in the past. Rather, he located it in the quotidian - in the everyday life of the individual. Second, he explicitly sought a source of authority to account for human behaviour beyond the usually accepted authority of Church or Crown. By substituting the notion of 'market' as the prime influence upon human behaviour, it could be argued that Smith was engaged less in a conscious act of subversion so much as assigning Church and King to a second-order category, which is rather a benign form of LèseMajesté! The role of Church and Crown lay not in regulating those aspects of human behaviour that advanced the workings of the market so much as preventing those that stood in its way. By contrast with Locke, for example, for 
whom access to and possession of, property was the foundation-stone of an established social order under the rule of Church and King, for Smith the social order revolved around the market place, the success of which lay in the willingness of Church and Crown voluntarily to stand to one side. Success of the former lay in the degree of self-limitation the latter two parties were prepared to exercise. It was, in short, a contract based on institutional restraint. But it also posed a tension that remains unresolved to this day: how determine the boundaries between individual freedom and licence on the one hand and regulation by authority and proceduralism in the name of the collectivity that is, the General Good - on the other?

This was an important distinction in two respects: first, Smith transferred restraint from the individual to the two major governing institutions of the day, whereas Hobbes placed restraint upon the individual, a restraint actively exercised by Leviathan — that is, by collective authority. Second, the distinction was important because Smith's notion of the social contract lay precisely in the daily freedom of individuals to pass and engage upon contracts, each in keeping with his own perceived interests. In other words, the Social Contract was a construct aggregated up from below and based on, myriad, everyday versions of the same. Accordingly, Smith's version of the Social Contract was not static. Nor was it set in stone, which it most certainly was in the case of Hobbes. Still less was it limited to what today may, by deliberate recourse to anachronism, be identified with the restricted concept of the Stakeholder Society (Neave, 2003), which underwrote possessive individualism in the case of Locke. Finally, Smith's view of the Social Contract did not rest on the concept of social stability imposed from above, so much as on the notion of a society made dynamic through competition, negotiation and agreement exercised individually and daily from below. To Smith, the overarching Social Contact emerged through the guarantee by authoritative institutions that these activities could be pursued. That, no more and no less, was to become the central credo and meaning of Liberalism.

\section{La Morale de l'Histoire}

What is evident from this short excursion into the historical origins of the Social Contract are the very considerable differences in the assumptions, procedures and ways in which each particular edition set out to sustain the social order. And from this it follows that they are very far from being compatible, one with another. For instance, while Smith made competition the touchstone of his Social Contract, for Hobbes, this same human trait engendered the worst of excesses that made the State of Nature so feral, where 'the hand of everyman is turned against his neighbour' (Oakshott, 1972). 
Competition was most certainly one of the activities the responsibility of Leviathan was actively engaged to restrain.

Hence, it is as well to be clear when one talks in general terms about revising the Social Contract, about which particular edition of the Social Contract serves as one's point of reference. For, as we have seen, the same human behaviour serves to illustrate a very different state of affairs and a very different sense of the direction in which we are moving. Progress in 'competitive freedom', seen with the metaphorical spectacles - rose tinted - of Adam Smith, may just as well be interpreted as a calculated cancellation and a unilateral tearing up of the Social Contract by our present day Leviathans, when viewed with the dark foreboding of Thomas Hobbes. Whether this latter policy will lead to a return to the State of Nature, decked out in the trappings of privatization, precarity in employment and the relocation of industry in exotic parts, is a matter of erudite and continual debate since the issue it entails stands at the heart of contemporary politics namely, the bounds of freedom, the limits of regulation, to whom they are to apply, in what territorial setting and with what rigour or complacency.

\section{The Approach Roads to a New Social Contract?}

Under what circumstance can it be said that the existing Social Contract has gone the way of all flesh and needs to be replaced by another? Some answers are given in this issue of Higher Education Policy. The first explanation is given by Zehev Tadmor who focuses mainly - though not exclusively - on the specific pressures that bear down on the higher education system. To this extent, Tadmor's analysis can be seen as a predominantly internalist and sectoral account. It does not specify the particular version of the Social Contract, which has come under the hammer other than noting that earlier and established conventions are no longer observed. If one were to risk reading into Tadmor's analysis more than he intended - which is unfair at the very least it would not be misplaced to see his implicit notion of the previous Social Contract as falling into a perspective that is strangely historical. In his reasoning, the two basic features of a Social Contract are its stability and continuity. This is not far different from the classic definition of a 'tradition' which is 'That which has persisted beyond the memory of Man' usually taken to be one generation - best operationalized as 30 years. In other words, the basic elements in the Social Contract are acquired and accumulated over time as part of a largely accepted and integral whole. It is only when individual elements begin to dissolve - the assumed non-interventionary stance of government, the unprecedented intervention by business which sees higher education as a new source of profit, the uncontrollable cost of technology, the 
weakening of ties between students, parents and professorate plus the frenzied drive towards research funding to the detriment of teaching - that one suddenly wakes up to the chilling conclusion that what for long has been held to be both viable and accepted, is neither one nor the other. It is perhaps the very simultaneity in the sudden multiplication of problems in the place of established practice and the change of practice into problematique - that accounts for the central thesis of complexity as an inseparable part and specific feature of contemporary higher education policy.

The most striking feature of Tadmor's account is, however, a certain parallelism it displays with Adam Smith's construct of the Social Contract. Such parallelism is not the predominant weight placed upon the economic aspect of change in higher education, though this is very certainly evident. It is rather the notion that a new Social Contract emerges bit by bit from out of the separate negotiations around individual elements - whether student funding; research funding, conditions of service for even for that matter the establishment of Quality assurance and accreditation procedures, as Huang Futao's article develops in the Japanese setting. Gradually, these individual and often separate issues begin to take on an aggregate profile. As with Smith, so it appears with Tadmor. The Social Contract surfaces from the multiple and individual dealings, not even conducted with the same interlocutors and very certainly not with the same end in view. If this is the usual way the New Social Contract takes shape, then it is no less clear that in its early stages it can scarcely be credited as such. It is, rather, a cumulative series of individual measures of good husbandry which, only later, have the descriptor of 'social contract' dashed upon them, sometimes by political parties, anxious to demonstrate consistency in thought and planning, sometimes by others who have suddenly become alert to the possible long-term implications the new aggregate entails. In both cases, the sudden identification of this process in terms of a Social Contract appears to fall into that very old reasoning contained in the ancient Latin adage Post hoc, propter hoc.

\section{A Second Account}

There is, however, a second account. This is developed by the late Stephen Stour whose last article Higher Education Policy is privileged to publish in this issue. Stoer's interpretation of the Social Contract departs from the proposition that the elements of change reside wholly in a technological or institutional perspective. On the contrary, they are, he argues, rooted in the cultural domain on the one side and on the other in the weakening of the hold the Nation State exercised until recently over the identity of minority groups. The centrepiece in the new Social Contract, Stoer argues, is not to be found in 
the instrumentalism of current EU policy. Nor is the momentum that, in his view, drives towards a revised Social Contract to be defined in function to territoriality. It resides in the determination of individual citizens to take back the power to define 'their own life-style'. Once asserted, this right in turn serves to define a series of new identities built around the ethnic group, race, gender or personal proclivities.

Unlike Tadmor, Stoer does invoke a specific school of contractualist thought,that of Rousseau. Much of his argument reflects Rousseau's basic contention, namely, the nobility of the individual when in the natural state and the oppression that resulted from the basic contractual relationship which yielded up to the civil state the individual's freedom and personal sovereignty. While Tadmor's view on the disappearance of the earlier 'contract' is one of a resigned realism, Stoer sees it as a prior and necessary condition for the-selfliberation of the individual the better to reclaim the right to define his - or her - own identity. And thus to make his - or her — choice as to which collectivity shall receive the individual's allegiance - in truth, an event much to be welcomed.

This is an interesting approach because it lays bare one of the major paradoxes behind the contractualist school of political thought namely, despite its advancing ideas and constructs that were supposedly applicable to all Mankind, such ideas developed in very specific national and political settings. This is not to decry the influence they had outside their land of origin - the United States in the case of Locke - and radical nationalism that fired both the French revolutionary wars and the reconstruction of Europe that followed them, of Rousseau. But, it does suggest that the forging of a Social Contract that balances respect of the individual along with recognition of the rights of the collectivity on a world level and other than on the basis of the lowest common denominator - cash - is a redoubtable task indeed.

For Stoer, the main forces that change the Social Contract take the form of a species of organic dissolution from within and while this interpretation may carry weight, it is exceedingly weak when it comes to a vision of what is to replace it. Certainly, it will entail the 'multiplication of constituencies' that reach across Nations. And, like as not, their inner cohesion will be reinforced further as their identity is integrated into the political process. It remains to be seen, however, whether such multiplication, democratic in itself one hopes, will give rise to a society grounded in consensus or simply multiply conflict exponentially.

What then is Stoer's vision of the new Social Contract - the Network Society? Regardless of the metaphor used to present it, let alone the claim that the 'network State (an oxymoron if ever there was one) is already among us in the shape of the European Council of Ministers, this is surely to confuse baby with bathwater. The 'network society' and a fortiori 'the Network State' - 
however defined - may indeed provide the incubator for a new Social Contract. ${ }^{2}$ But they are not themselves a Social Contract, let alone a new one. Stoer's vision is not one of a new Social Contract so much as an analysis of the dissolution of the old. He does, however, lift up the curtain by using a series of metaphors as illustration to what might emerge, the last of which is the Kuwaiti Bazaar. Bazaars are indeed exciting places to be in. But even in those colourful societies where they flourish and haggle from morning to night, they do not engulf the whole town. They are very specific, though naturally central, enclave. Whether the Kuwaiti bazaar is simply an ethnologist's depiction of Adam Smith's market place projected in culture's equivalent of Glorious Technicolor, is something readers must decide for themselves.

\section{Example of Collapse}

While the Social Contract may evolve, it is rare for it utterly to collapse, though this is precisely what happened in varying degrees in Central and Eastern Europe and very particularly so in Russia. In their article on the development of higher education policy in Russia during the 1990s, Gounka and Smale do not focus on this particular aspect as such. Rather, they focus on the influence the main doxological agencies of the World Bank and the Organization for Economic Cooperation and Development has had on the shaping of Russia's policy toward higher education. Nevertheless, their contribution does provide us with useful insights into some of the consequences that follow from so unusual an event as the implosion of the Marxist Leninist equivalent to the Social Contract. In effect, they give us an interesting penetration into an issue posed earlier namely, under what circumstances can the Social Contract be said to have ended? Ironically, the answer to this question draws in part at least on the well-known observation of the late Vladimir Ilytch Ulianov, otherwise known by his nom de plume as Lenin. In that manual for the perfect revolutionary, The State and Revolution, Lenin identified one of the preconditions of revolution as the loss of confidence by the ruling class in its historic mission, that is, in the intimate conviction of its uncontested ability and right to rule.

\section{Lenin and George Bernard Shaw}

Given what has subsequently emerged out of the ostensible switching from a Social Contract defined within the canons of Marxist Leninism towards one that professes a certain kinship to the model first outlined by Adam Smith, Lenin's insight requires a little modification. For effectively, the nomenklatura that flourished under one form of Social compact, rapidly ensured its own 
survival by taking over the means of production as its own personal possession. With the means of production thus literally in hand, the nomenklatura mutated with the greatest of ease into a kleptocracy. It then set about building another social compact that would redefine behaviour previously criminal under the earlier Contact to become entrepreurial and praiseworthy under a new one and thus permitting the kleptocracy to retain sudden gains, ill-gotten fortunes and attain respectability (Tomusk, 2004, 76-87). Clearly, such versatility unveils another possibility that Lenin did not anticipate. It was, however, anticipated years before by another individual of acerbity and wit - the Irish playwright, George Bernard Shaw. Thus, the Russian nomenklatura, like the gentleman their functional counterpart in English society - 'played fair until they lost. And then, they changed the rules of the game'.

If the breakdown of the social compact based on the collective ownership of the means of production is devastatingly clear, by what type of social contract it is being replaced, most certainly is not. Are, we for instance, to interpret the abolition of Russian academia as a full-time job, and for the majority of Russians, the wiping out of pensions, social security, the dramatic fall in lifeexpectancy among men as indicating a partial return to a Hobbesian state of nature? How are we to interpret the behaviour that such a massive social break-down imposes as the price of individual survival? Is the sudden scrabbling around by all, including the most able and talented, to ensure the survival of their families by taking on two or three jobs in addition to the one that once paid their bread, evidence of the virtues of flexibility? Are we also to see the sudden blooming of 'universities' in nooks, crannies and other strange places, got up by academics desperate to make ends meet, as evidence of entrepreneurial 'derring-do'? Is the rushing after dollars, euros and roubles that devours so much of the life of individuals and institutions - and individuals within institutions, as Gounko and Smales make plain - the frantic twitching of the university world in an effort to avoid the blackest of poverty, is all this to be blandly presented as 'revenue generation'? As evidence of late blooming managerial acumen? Or are we to take such frenetic behaviour as a personal comfort that such fundamental features of competition are sure signs that capitalism is to be found even in the State of Nature itself? Are we to conclude that, for others, there is nothing wrong in returning to near bestiality if it allows a social compact grounded in economic liberalism eventually to stick its head up amidst the ruins?

\section{The Return to Ambiguity}

The list of ambiguities is endless. And just as ambiguous is the way the very behaviour one would expect in times of dire distress, is interpreted by the 
masters of our latter day Doxology as supporting their undeniable and infallible teachings. Nor, in this particular connexion, is it coincidental in the slightest that the Lords of Economicism should step in to the vacuum, created by the dismantling of the Russian collectivity, to preach the good word of their doctrine, as a consolation to those who have lost all and a benediction to those who have pocketed all. At this point, an amazing and unsavoury similarity springs to mind. As the American radical, Tom Paine, an ardent supporter of the Revolution of 1789, remarked about the hand-wringing by Europe's nobility over that event, so one might judge the policies of both World Bank and OECD towards higher education in Russia: 'They admire the plumage but forget the dying bird.' Just so. Quite.

That the collapse of one social contract appears to have served the interests of a very particular class, group or clique in whose interest it is to forge another Contract to maintain their privilege under new trappings and under a very different guise indeed, raises a question, more fundamental yet. How far is it possible to separate the Social Contract from a political - or for that matter, an economic - agenda? Can a Social Contract effectively be above the particular social order that gives rise to it? Or is it merely a construct, which though based in ideology, is better reasoned, more coherent, less dictated by opportunity, is balanced across the full range of human activities, that shows favour to none and ostensibly is superior to ideology on that account? Or should the assembly of an acceptable Social Contract be inseparable from fashion, ideology and the will of the Prince, his court or his Commissions?

\section{Conclusion}

Editorials act as backdrop to the articles that follow them. They serve as an introduction. They highlight the common points and issues that authors have lit upon, each independently. I have stayed within these bounds. But, I have also dug rather deeper within them. I would justify this by arguing that, if we are to discuss - let alone set about constructing so essential a reference point for human endeavour, hopes and happiness as a new social contract - it is as well to have a little clarity about where we stand on the matter, on what has been done before and what light earlier ways of thinking this topic through casts upon our present state.

Perhaps, it reflects the complexity of the issues higher education believes it faces today plus the ever-growing and differing perspectives that can be brought to bear on them, that we tend to be a little over-indulgent in the usage of terms. This is dangerous for ourselves and no less so for those who from time to time take up and rework the happy phrase or who build hastily on what 
we have done. Overexposure and the slack use of terminology evacuate meaning. Worse, they reduce it to a slogan that makes a striking impression but defies any real sustained thought. If one should seek an example of this phenomenon, there is one immediately to hand: 'The university'. It is surely one of the most outrageous ironies of the decade that, as the study of 'higher education' has been enriched by inquiries without number, by the application of intellectual perspectives and techniques combined in the most imaginative, original and sensitive manner, we are no longer capable of agreeing what a university is, though all want to call themselves universities — which is imbecility compounded, just as it is an easy curse of action for governments to take.

There are several signs to suggest that fashion - that malediction on scholarship, regardless of whether or not our field is wise in being one of its dedicated followers - is about to move into examining the notion of the Social Contract. In all likelihood, it will take as its point of departure the concept of contractualization and blindly construe the Social Contract - at least as it applies to higher education - in terms of the extension, intensification and application of that principle to all areas coterminous with the higher education system. Or as another scenario, to set contractualization as the artifactual basis for higher learning across the face of Europe of the 25. This, I have argued, would be a stunted vision - a dwarfish version; if you will - of the Social Contact since it reduces the Social Contract to being driven and shaped by one predominant canon - that of Economics.

The point of this Editorial, however, has been to show that there are many forms of Social Contract, with vastly different consequences for the social construct they sustain, even within the precise limits set by the founding fathers of contractualist political theory. They made different presumptions about human behaviour. They projected very different forms of social construct. One thing they had in common, however, and which stands in marked contrast with one of our central preoccupations today is the place of change. Neither Hobbes, Locke nor Rousseau grounded their theories on change, though Smith, as we have seen, did, at least within the that enclave which the marketplace represented. But the marketplace in Smith's time was itself a limited space, confined within a larger social web that remained steeped in what is best described as 'ancestral' or 'pre-economic' folkways.

The variety of interpretation within the Social Contract is also evident from the articles that make up this issue of Higher Education Policy. They illustrate with extreme nicety the range of interpretation from the perspective of Science Policy developed by Tadmor, to the changing behaviour of groups, analysed by Stoer and the examination by Gounko and Smales of the way one singular interpretation of the Social Contract determined national policy. 


\section{A Parthian Shot}

Redesigning the Social Contract is a matter which, even if taken at face value rather as a coded allusion, deserves extreme vigilance, both on the part of the higher education community, and by the citizens of Euroland in general. A Social Contract, as this Editorial overview has made plain, is not a Constitution, though slippery linguistic footwork could argue that it is a formalized and partisan variant - a sub-set within the general category. So one has to be alert to the coded meaning as well. After all, the practice of terminological versatility has a history in the higher education policy of Euroland, though not necessarily a glorious one. The neat argument that 'a common architecture' was not quite the same thing as 'harmonization' in higher education was the 'Open Sesame' that launched the Bologna Process.

Given the lack of enthusiasm Euro-voters showed - where they were permitted to vote - for a European Constitution and given the fact that the ladies and gentlemen gathered around the Rond Point Schuman, are exceedingly reluctant to take a No for an answer, especially when it reduces their ingenuity to dust and ashes, there is good reason for thinking that similar semantic shinanigins lie behind the suddenly acquired interest in Social Contracts. If words have meaning, they do not necessarily have the same meaning for everyone and most certainly not when the issue involved literally dares not say its name. So, on the principle that 'A rose by any other name doth smell as sweet', we must resign ourselves to the possibility that the fashionable preoccupation with so-called Social Contract is simply a device to re-introduce through the back door what was recently heaved without ceremony out through the front.

Still, there is much to rejoice over. If the President of the Commission and his advisers continue their merry way, they will very certainly achieve a resounding 'First'. For in the long history of political thought and political philosophy from Plato onwards, no philosophical construct has ever yet been designed by a committee. At least, not one that has survived and figures in the Pantheon of Thinking about Man's estate. It is exceedingly heart-warming to know that the ancient tradition of Philosopher Kings lives on in these latter days and that it entertains ambition for itself and for the rest of us.

\section{Notes}

1 Indeed, life under such conditions tended to be 'poor, solitary, nasty; brutish and short' Thomas Hobbes Leviathan.

2 Given the results of the bid to introduce a 'European Constitution', one is certainly justified in suspending belief and for that matter, confidence in the ability of that same Council of Ministers to act as the vehicle for a Social Contract, though the latter may be perpetuated by talented writers and philosophers without the slightest necessity for anyone - not even the 
Council itself - to vote it! That in itself has its appeal, no doubt, so the notion of a New Social Contract has much going for it.

Guy Neave

E-mail: g.neave@bbt.utwente.nl

\section{References}

Fukuyama, Franccis (1992) The end of History or the Last Man, New York, Penguin.

Lenin, V.I. (1954) The State and Revolution, Moscow: Foreign Languages Publishing House.

Neave, G. (1996) 'Evaluating Higher Education: France', in World Yearbook of Education, London: Evans Brothers.

Nybom, T. (2003) 'Reflections on the past, present and future of the European university', Higher Education Policy 16(2): 141-159.

Oakshott, M. (1972) Hobbes' The Leviathan, New York: Collier.

Pollitt, C. (1993) Managerialism and the Public Service, Oxford: Basil Blackwell.

Tomusk, V. (2004) Open World and Closed Societies: Essays on Higher Education Policies 'In Transition', New York: Palgrave Macmillan. 